\title{
Ferdynand Kasler's architecture of harmonious modernism
}

\begin{abstract}
The subject of the article is the study of works, created by architect Ferdynand Kasler in the interwar period in the city of Lviv/ Lwów/Lemberg, Galicia. It depicts the urban and residential development of the city and the role of modern architecture. Using examples of the works built by Kasler and other architects, the author demonstrates, that Ferdynand Kasler was the founder of the direction of "harmonious modernism" in the mainstream style of architecture of modernism. Unfortunately, he was murdered during the holocaust and forgotten as a very important architect of his time.
\end{abstract}

Keywords: Architecture, Ferdynand Kasler, harmonious modernism, Lviv

If we look at the so-called "genetic plan" (ill. 1) of the central part of modern day Lviv, which reflects the scale and planning structure of its development and its relation to open spaces, then we will see the real space and meaning of the period of antebellum modernism in the urbanist geometry of the city. Buildings were concentrated in the former 1st Halickie, and 4th Łyczakowskie
Districts, which were notable for having the lowest population density (about 4,000 persons $/ \mathrm{km}^{2}$ ) and had the most usable resources on their territories. These districts lie to the South and East of the city. In the very geometry of the buildings one can see, that it mainly concentrates on filling already existing, not adding on to First World War neighbor-

III. 1. Interbellum construction (red) in the structural ("genetic") map of the central part of modern day Lviv. Source: Bohdan Cherkes. Graphic assistance: Natalya Mysak

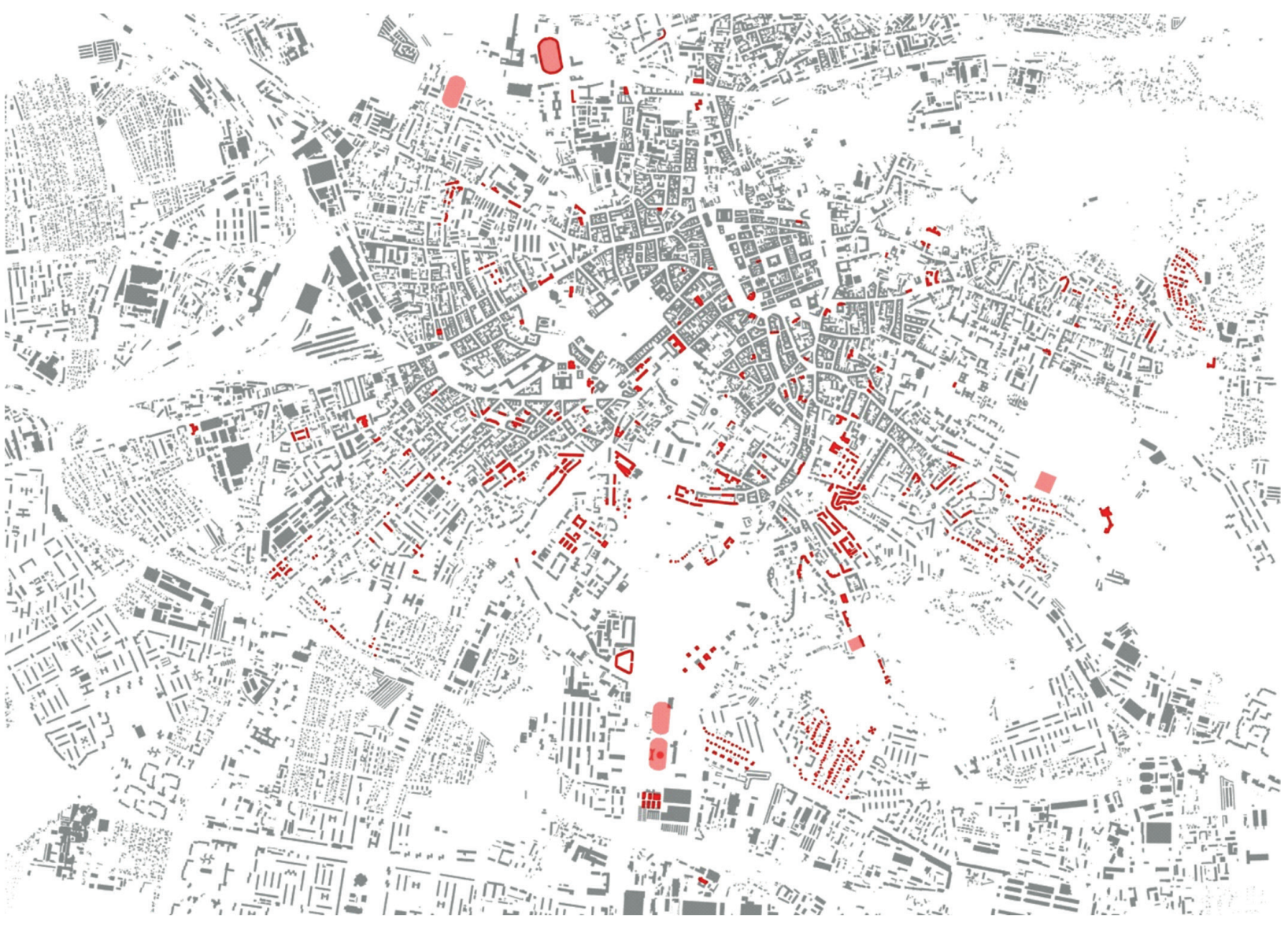

* Prof. dr. hab. inż. arch. Bohdan Cherkes, Faculty of Environmental Engineering and Land Surveying, University of Agriculture in Kraków, 


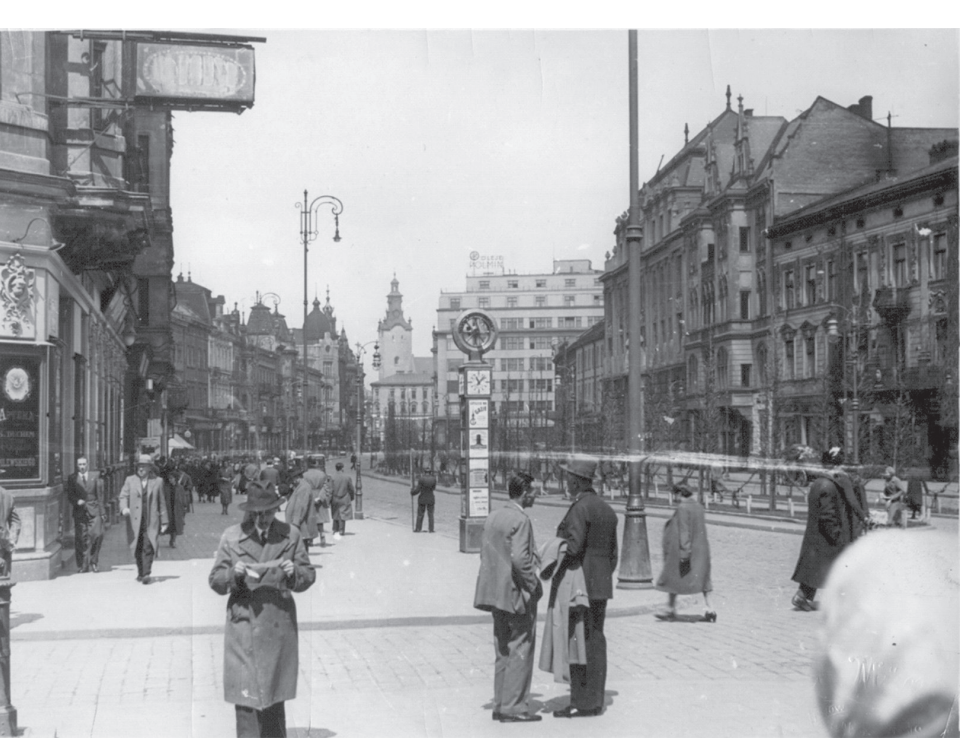

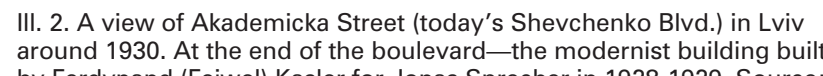
by Ferdynand (Feiwell) Kasler for Jonas Sprecher in 1928 .
Marek Munz, photo $13-18 \mathrm{~cm}$. L Lviv Historical Museum

hoods. Along the periphery of the expanded city, thanks to villages after 1931, Lviv forms a fragile single-family development of various architectural character (Krzywczyce, Kozielniki, Persenkówka, Pohulianka, Sofiówka,
Bohdanówka). According to its planning structure this is a transitional style between urban and rural buildings, ations ("Professor's Colony," "Own Roof," "ron Water, and "Bohdanowk") appeal to the popular at that time in Europe Howardese ideas of garden-cities. The architecture of such a building often uses the motives of so-called "manor-house style, "zakopane style" and olher folk and decorative motifs that often had little in common with the principles of classical modernism.

Ans architecture of Lviv modernism as one that was formed that it was created lar evely by tho are priples, is worked in Lviv up to the First World War. Almost al of them were graduates of the "Lviv Polytechnic school of archistecture. Witold Minkiewicz, Ferdynand Kasler, Jan Bagieński, Tadeusz Wróbel Leopold M. Karasiński, Józef Awin the younger Zbigniew Wardzała, Andrzej Frydecki, Eugen Nahirny Ryszard Hermelin, Jakub Menker, Henryk Sandig, the main creators of Lviv's modernism, were activeIy connected to Lviv and to the traditional Galician cultural environment.

Consider this evolutionary or harmonious manifestation of modernism using the example of severa urban ensembles in the city. One of the most famous and popular representative spaces of the city is now Shevchenko boulevard, formerly known as

Mr. 3 . Ferdynand Kasler, the architectural drawing of the main façade of the Sprecher Building, Akademicka Street 7, Lvivi, 1928. Source: State
Archives of the Lviv Oblast (further DALO), fund 2, description 1, case 42, sheet 16, Fasada gtónna od strony bulwarów (Main Façade from the

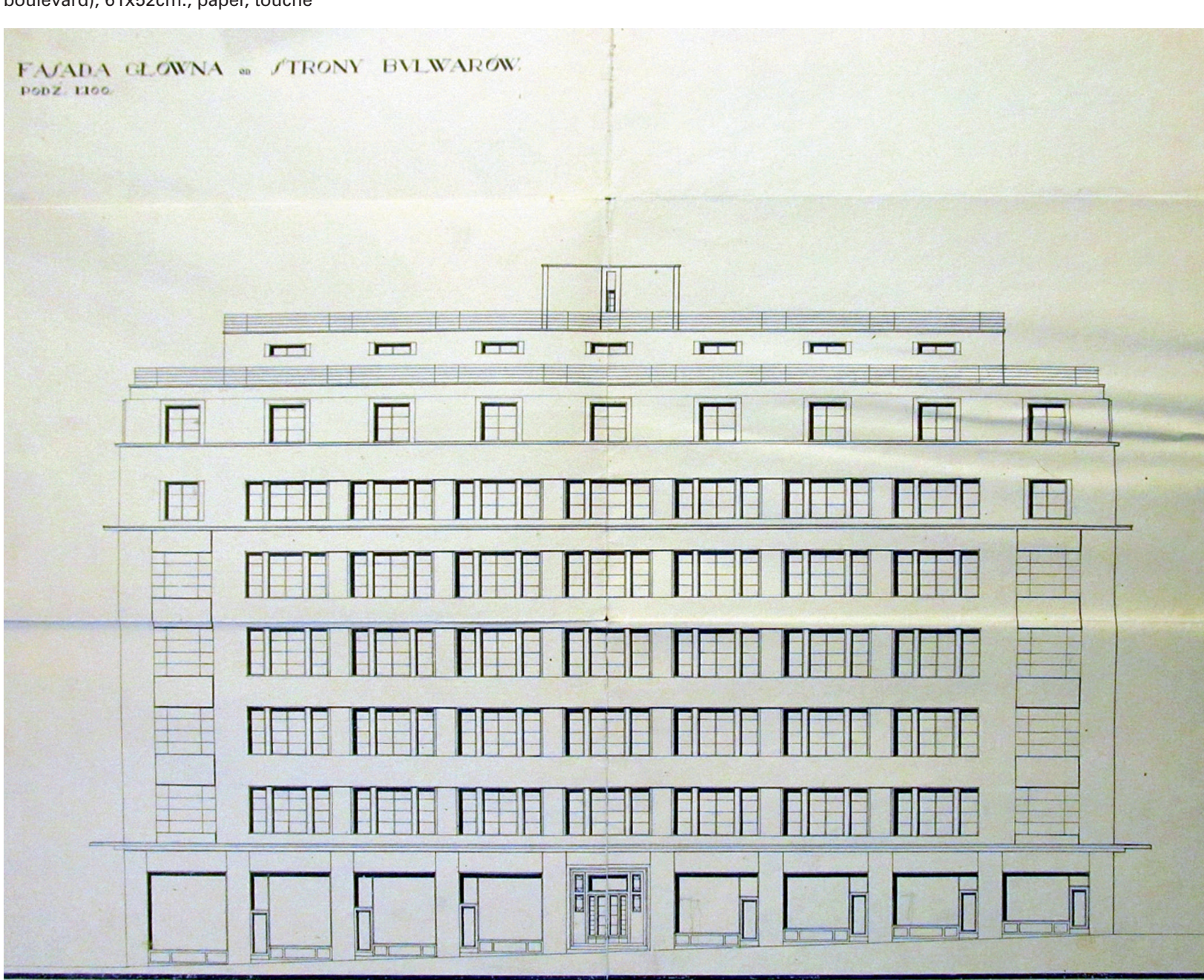

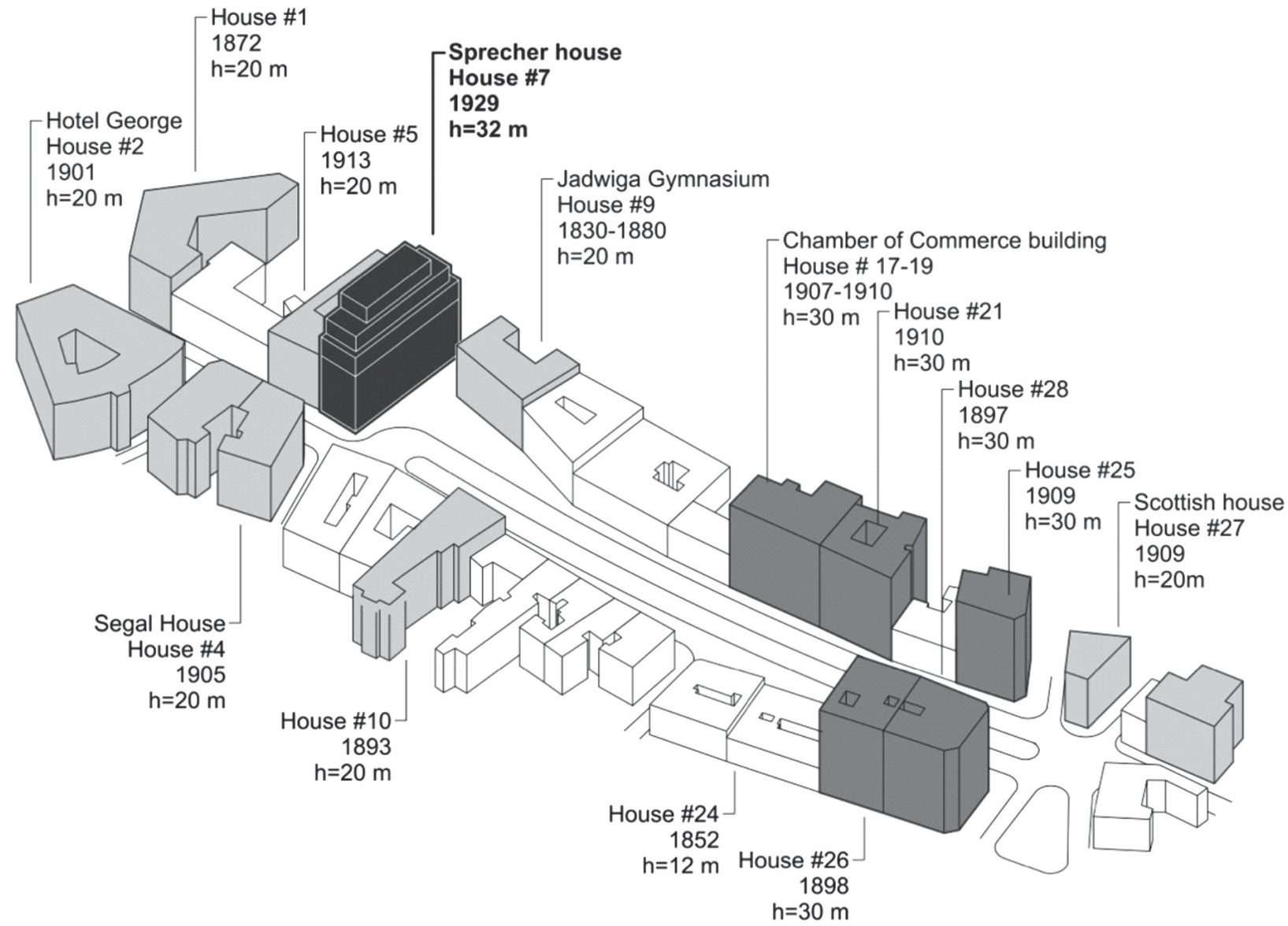

III. 4 . Image depicting the architect
hic assistance: Anton Kolomercew

Akademicka Street (ill. 2). ${ }^{2}$ Although the area as a settle ment along the Poltva was already known from the 15 century, as a street it started to form in the 18 century, especially after the Lviv University was moved to the former Jesuit Collegium on St. Mkolaya Street in 1848 . However, it came to take on its current representatio only after 1896 when the Polva River was channeled underground. Along its axis a green boulovard was creatThe Mong the Avenus agreentill bl, which was buit in 1928-29 by Ferdynand (Feiwel) Kaster for the entrepreneur Jonas Sprecher was the last fundamenta tructure and completed the formation of a representative area on the north the fide, before it flowed into Mickiewicz Square (formerly Mariacki square) and the into the main avenue of the city - today's Svobody Boulevard (formerly Legionów and Hetmańska Streets) Here also opened up the view onto the Latin Cathedral, and across Teatralna Street (formerly Rutowskiego) on could enter the historic city center. Prior to Kasler an entire pleiad of dazzling Lviv architects of the older generation, particularly Tadeusz Obmiński, Jan Schulz, Alfred Zacharijewicz, Julian Cybulski, Jakub Bałłaban worked on the boulevard. The main architectural directions in which they worked were various neo-styles, eclectic and secession, characteristic of the turn of the nineteenth century. Building height ranged from 10 to $30 \mathrm{~m}$ and the silhouette, despite the high quality of elaboration and richness of the plaster facades, gave a rather chaotic impression. However, the overal trend was pointing to increasing the height of the buildings (ill. g). Thus, new buildings that were built at the beginning of the avenue, from the end on (formerly A stands hic monument to Hrushevsky Street 25. architect Jan Schulz, 1911) were already a Nost $30 \mathrm{~m}$. high including their attics. This was mor than 20 meters higher than the average height of the buildings on the avenue which were built in the middle of the nineteenth century, which can be seen in the oldest house on the avenue under $\mathrm{No}$. 24, built back in 1852 .

This trend of monumentalizing and radically raising the height of the buildings on Akademicka Street at the turn of the century, is well demonstrated Chamber of Commerce) under No. 17-19, built in 1907-1910 by Alfred Zachariewicz and Tadeusz Obmiński. ${ }^{3}$ The height of the building (about $30 \mathrm{~m}$.) set centrally on the avenue across from today's Du(2) Jakub Baltian 1897 and on the old side: No. with today's Prosecutor's building (formerly the 


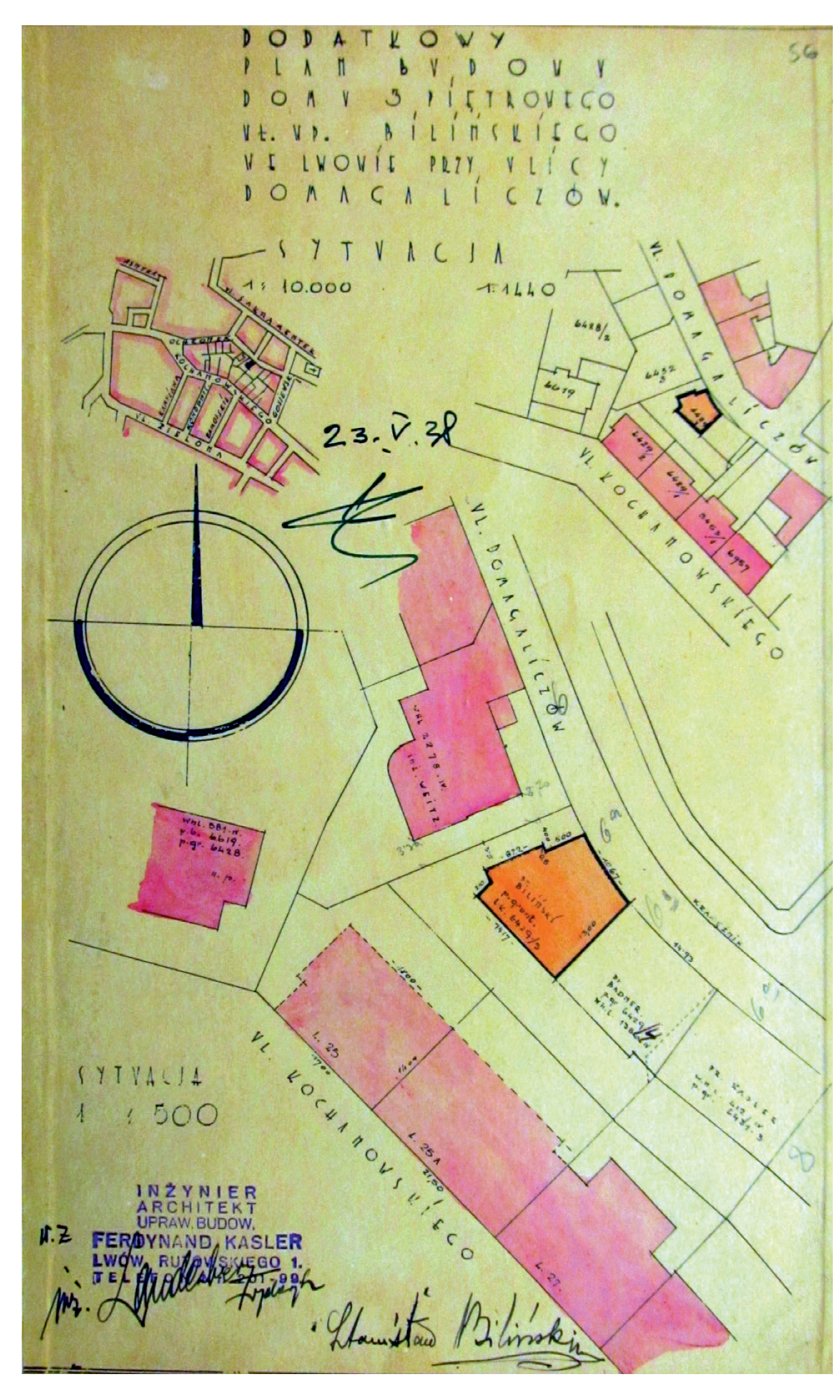

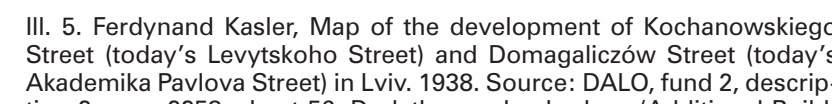

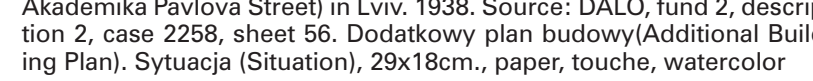

dayeva Street (former Zimorowicza), the use of expensive materials and forms of monumentalizing secession fixed the new grand scale of Akademicka Street. It is no Jan Schulz buitt idjacent house, No. 21, designed by tectural style preserved the new scale of the boulevard. Ferdynand Kasler, receiving orders for the second highrise Sprecher building in the mid -1920s, was in a very difficult position. The customer was demanding a revenue producing office building but had had a bad experience interacting with Lviv restorers, particularly with Tadeusz Obmiński, who was the main conservator of Lviv's monuments. It was this situation that caused Kasler to redesign the project and reduce the height of the first Sprecher building, which was finally built on Marjacki Square in 1921. 4 The new situation was also complicated by the fact that across from the plot where the second Sprecher skyscraper was to be erected stood one of Obmiński's best works of the Secession period - the Segal building (Akademicka Street, No. 4), built in 1905. (ill. 4). Additio- nally, the site was very narrow and measured 11.1 m. by $49.8 \mathrm{~m}$.

It must be acknowledged that Kasler, brilliantly coped with his task, designing a modern building out of a reinforced concrete frame and neutral functionalist forms. The total height of the building was $33.51 \mathrm{~m}$.; it consisted of two underground and eigh above-ground floors of variable height (from 3.65 in the top floor to $4.1 \mathrm{~m}$. in the basement) and ledges that extended from the main facade of the 7-8 floors. ${ }^{5}$ Aside from the rhythmically spaced large windows, the entire building is encircled by horithe first fifth and sixth floors. With the her edge of the first, ing with the heights of Tadeusz Obminki's Sega building the heights of Tading tionately refined eclectic residential building at No. 5, built in 1913 by Jan Schulz.

Additionally, Kasler's Sprecher building skillfully completed the entire urban composition of Pros pect Shevchenka, combining into a single unit its entire 394-meter length from today's square hous ing the monument to Hrushevskiy (formerly Akademicki Square) to Mickiewicz Square (formerly Marjacki Square). Using the laconic language of architectural modernism, he was able to combine the above described eclectic system of the main landmarks of Akademicki Street and transfer it to another, more representative spatial scale. Due to the strong neutral blocks of modern architecture it was possible to allow for a wide boulevard that ranges from $33 \mathrm{~m}$. at the start, to $37 \mathrm{~m}$. in the middle by the former Chamber of Commerce -and spreads to 60 $\mathrm{m}$ in front of the Sprecher building before flowing into the narrow $18 \mathrm{~m}$. wide section of Shevchenk Boulevard and spilling onto the broad expanse of Lviv's main squares and representative avenues around and in the center of the historic center. These principles of harmonious modernism were used by Ferdynand Kasler in other parts of the city. In particular, as an architect and urbanist he participated in the creation of the residential area on Levitskiy Street (formerly Kochanowskiego) and Academician Pavlov Street (former Domagaliczów) the pictures the hills of Pohulyanka and along which coursed the border betwe the 1st Halickie and 4 kyczakowskie Districts. 7 Even before the war in this area, Kasler designed an entire series of large-scalo residential buildings using steep tiled roofs, large window openings, balconies, bay windows, as well as elements of classical architecture and monumentalized secession. These residential building include the very popular and expensive residentia complex on Kochanowskiego Street No. 11-15 and the large-scale (height $32 \mathrm{~m}$.) building No. 26 with elements of eclectic and German Romanticism. Therefore residential buildings No. 25-25A (ill. 13) which Kasler built for Dr. Badnera in 1938, literally in front of his own pre-war building No. 26, were actually an extension of his work at a new stage of development, using interwar modernism, language and principles which he had mastered brilliantly.

An example is the next building on the street which runs parallel to Kochanowskiego Street, Domagaliczów 6A (currently Academica Pavlova Street), which Kasler built for Stanistaw Bnitski 1938-39. The next buildings $h$ e built at that time, on the basis of functionalism for $\mathrm{D}$. Badnera (No.8) and Franciszka Kasler (No.10), formed the entire Domagaliczow Street, in which Kasler, on the very eve of the start of World War II, finally declared the principles of harmonious modernism, as the main ones we tok the existing uran heas, the existing unban scale and the need for is ing environment and objectives which exist at the cretion of any urbanist composition (ill. G).

Unfortunately Ferdynand Kasler suffered the tragic fate of many prominent people, especially Jews of his generation. In 1943 he was murdered by the Nazis in the Janowski concentration camp near Lviv. ${ }^{9}$ History viewed him and his legacy so cruelly, that practically no documentary evidence of this remarkable man's life remain except for his architectural designs.

At the same time, the principles of harmonious modernism in interwar Lviv urbanism were professed by othe architects of the period. We see them in different interpretations of functionalist residential buildings between Kopernica and Doroshenko Streets (formerly Sykstuska Street), on the street Heroyiv Maydanu (formerly Kadecka Street), in constructions near Sakharova Street (formerly Wulecka Street) and Hlybokoyi and Novyy Svit Streets, in the works of Witold Minkiewicz, especially in his 1927 complex of residential houses of the aries' Pension Department on Stryiska Street No. 36-42 and further buildings (No. 50-76) on the same street. This principle of harmony, based on the rules of jurisdiction, spontaneity, scale, and agreeability with the formed urban structure or the city is one of the largest contributions made by the Lviv School of Architecture in the history of urban culture and urban modernism in general.

ENDNOTES

Prof.drhabininz.arch. Bohdan Cherkes, Faculty of Environmental Engi-
neering and Land Surveying, University of Agriculture in Kraków, ORCID

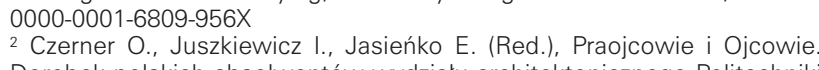

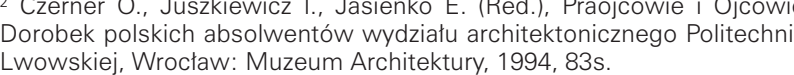

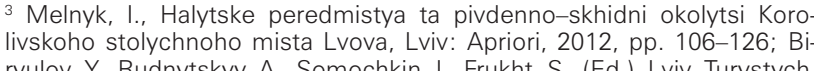

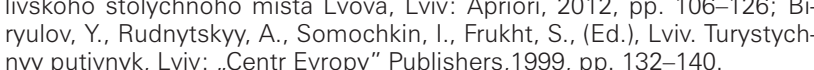

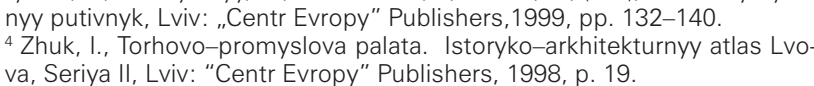

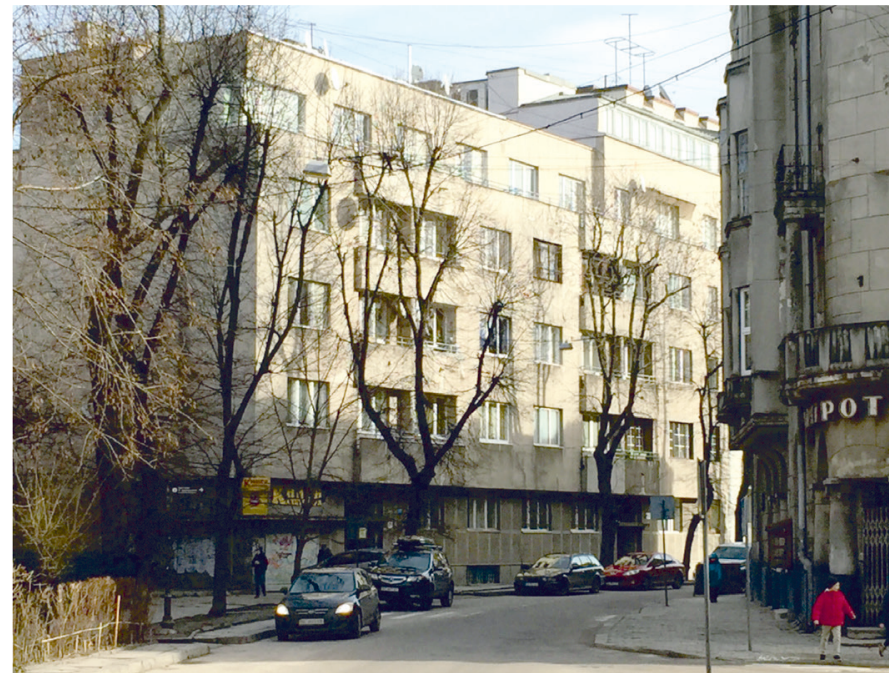
III. 6. Ferdynand Kasler, A view of the residential building on Ko-
chanowskiego Street (today's Levytskoho Street), $25 / 25 \mathrm{~A}$ in Lviv.
1937. Source: DALO, fund 2, description 1, case 5320 , sheet 100 , photo, $9 \times 15 \mathrm{~cm}$

s Biryulov, Y.(Ed.), Arkhitektura Lvova. Chas i styli XIII - XXI century,
2008 , pp. $485-487$. 2008, pp. 485-487.
6 DALO(State Archive of Lviv Oblast), Fund 2, Description 1, Case
42 Akademicka St. 7 . 18 sheets of drafts.

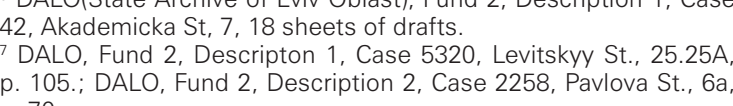
p. 70.; DALO, Fund 2, Description 2, Case 2258, Pavlova St., 6 .
Melnyk, I., Zahayska, R., Lychakivske peredmistya ta skhidn

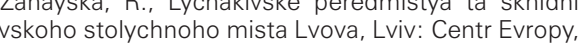
2013, p. $134-145$.
9 DALO, Fund 2, Description 2, Case 2258, p. 70 .

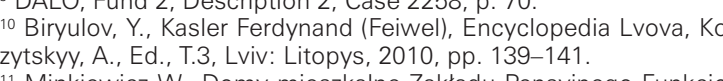
"M Minkiewicz W. Domy mieszkalne Zaktadud Pensyyinego Funkcio-

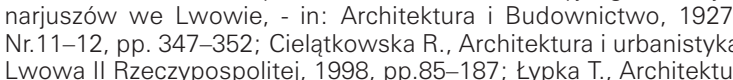
(a Lwowa okresu międzywojennego (1918-1939), - in: Lithuani

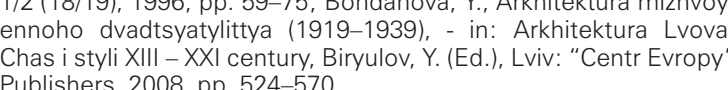

BIBLIOGRAPHY

作 [2], Biryulov.,., Kasler Ferdynand (Feiwell), Encyclopedia Lvova, Ko
zytsky, A. (Ed.), T. .3, Lviv: Litopys, 2010, pp. 139-141.

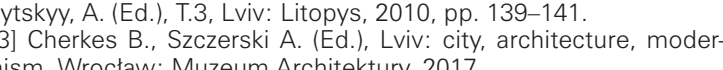
(4) Cielatatkowska R., Architektura i urbanistyka Lwowa II Rzeczypo-

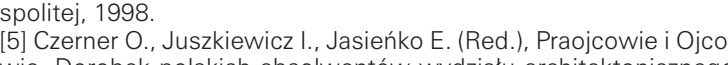
wie. Dorobek polskich absolventiów wydziatu architektonicznego
Politechniki Lwowskiej. Wroctaw: Muzeum Architektury, 1994. [6] Melnyk, l., Halytske peredmistya ta pirdenno-skhidni okolytsi 